\title{
An Investigation of Curriculum Adaptation Efforts of Teachers Working in Disadvantaged Secondary Schools
}

\author{
Mükerrem Akbulut Taş \\ Cukurova University, Education Faculty, Department of Educational Sciences, Curriculum \& Instruction, 05054958585, Cukurova \\ University, Education Faculty, Department of Educational Sciences, 01330, Balcalı/ ADANA,
}

${ }^{*}$ This study was published at the 6th International Conference on Curriculum and Instruction: Curriculum Studies in Secondary Education, (11-13 October 2018), Kars, Turkey" was presented as an oral presentation. Afterward, the theoretical part of the article, as well as the discussion, conclusion, and suggestions part were developed.

\begin{abstract}
There is a consensus that the national curriculum cannot be implemented in its original form in local context. Adaptations are made in curriculum due to factors such as school and classroom context, student characteristics and needs, teacher's professional competence and characteristics. This study aims to investigate the curriculum adaptation efforts of teachers working in socioeconomically disadvantaged secondary schools. This study used a phenomenological inquiry. The participants, who were selected using criterion sampling method, included the voluntary eight female teachers who worked in socio-economically disadvantaged secondary schools. Data were collected through standardized open-ended interviews and were analyzed using the inductive content analysis method. This study indicated four main findings: a) Students' family structure is the main factor determining disadvantageousness in socio-economically disadvantaged secondary schools. b) Student and family characteristics, curriculum and curriculum materials are the factors that frequently prevent fidelity to curriculum. c) Teachers made adaptations, such as reorganizing, supplementing, omitting/delaying, completing and reducing/simplification. d) In the adaptation process, teachers were found to experience difficulties associated with planning the instruction process and organizing and presenting the content. They were found to cope with these difficulties by benefitting from their postgraduate education experiences, collaboration with colleagues, and internet sources. Based on the findings from this study, families' awareness could be improved by preparing family education programs. Instructions could be prepared about how and in what situations adaptations need to be made while developing curriculum; curriculum materials could be developed, and professional development opportunities could be increased.
\end{abstract}

Keywords: Socio-economically disadvantaged secondary schools, disadvantaged students, curriculum adaptation, curriculum implementation, postgraduate education.

\section{INTRODUCTION}

There is a consensus that the national curriculum cannot be implemented in its original form in local context. Some studies have reported that adaptations are made in curriculum due to factors such as school and classroom contexts, student characteristics and needs, teacher's professional competence and characteristics (Baş \& Şentürk, 2019; Bümen \& Yazıcılar, 2020; Datnow \& Castellano, 2000; Li \& Harfitt, 2017; 2018; Reisman, 2012; Remillard, 2005; Shawer, 2010; Tokgöz, 2013). Curriculum adaptation is a complicated process that differs according to teachers' teaching skills and curriculum knowledge. In this process, teachers demonstrate an educational effort to preserve the connection between intended curriculum and classroom implementation. This effort has particular importance in increasing and maintaining the quality of education in socio-economically disadvantaged schools.

The curriculum is a guide used by teachers while designing instruction and deciding on classroom activities, what is learned, and to what extent they are learned (Remillard, 2005). However, there is a distinction between the intended curriculum and implemented curriculum. Teachers implement the intended curriculum by transforming it (Remillard, 2005). Hence, one should focus on the implemented curriculum to determine the effectiveness, productivity, and sustainability of the intended curriculum. This study focuses on how teachers who work in socioeconomically disadvantaged secondary schools adapted the national curriculum.

Corresponding Author e-mail: mtas@cu.edu.tr https://orcid.org/0000-0002-8398-9357

How to cite this article: Taş MA (2022). An Investigation of Curriculum Adaptation Efforts ofTeachers Working in Disadvantaged Secondary Schools. Pegem Journal of Education and Instruction, Vol. 12, No. 1, 2022, 10-24

Source of support: Nil

Conflict of interest: None.

DOI: $10.47750 /$ pegegog. 12.01 .02

Received: 12.08 .2021

Accepted: 22.11.2021 Publication: 01.01.2022 


\section{Theoretical Framework and Related Research}

\section{Socio-economically Disadvantaged Students and Schools}

Disadvantageousness, as stated by Özbaş (2018), is '....all negative conditions experienced by individuals in social life, economy, education, policy, socio-cultural processes; namely, in all areas of life in comparison to the middle and upper sociological stratum of society" (p.1145). Caillods (1998, p.10) defined disadvantaged groups as "are composed of those who, because of their economic situation, gender, ethnic or linguistic origin, religion, or political status (refugees) have less chance of being integrated socially and economically". As for disadvantaged individuals in education, "all those who either have no access to education or ... those who, after a few years of schooling, drop out without having acquired the minimum level of skills needed to manage adult life in the specific local and national context" (Caillods, 1998, p.10). Although disadvantaged groups may vary from country to country (Caillods, 1998) disadvantaged individuals could be considered as groups that are composed of individuals who do not have the social, cultural, and economic opportunities possessed by the groups that are not disadvantaged. This study analyses disadvantageousness for schools and students in terms of socio-economic aspects. Özbaş (2018) states that disadvantaged social stratums experienced disadvantageousness mainly in terms of socio-economic aspects.

Independently of their socio-economic and individual conditions, schools are institutions that need to provide quality education in equal conditions (Organisation for Economic Co-operation and Development [OECD], 2012). However, socio-economic infrastructure is one of the main factors that determine how much the school realizes this function. There is a significant relationship between socioeconomic indicators (family income, parent training, etc.) and students' academic achievement (Aydın, Sarıer \& Uysal, 2012; Chakraborty \& Harper, 2017; Dinçer \& Oral, 2013; Fındık \& Kavak, 2013; Şirin, 2005). The effect of socio-economic level on students' academic achievement in Turkish, Mathematics, Science, and Social Studies courses has been reported in Turkey and Programme for International Student Assessment [PISA] reports (OECD, 2012, 2018; Ministry of National Education [MoNE], 2017a; TEDMEM, 2019). Schools in the regions including socio-economically disadvantaged groups are also considered disadvantaged (OECD, 2018; TEDMEM, 2019). According to OECD (2018), disadvantaged schools are schools that are among the bottom $25 \%$ in terms of the economic, social, and cultural status indicators of the country. Among OECD countries, $48 \%$ of disadvantaged students attend these schools, and Turkey has this value (OECD, 2018). Socio-economically disadvantageousness significantly limits students' access to quality education and restricts their academic performance, leading to inequality for schools and students (Aydın et al., 2012; Dinçer \& Kolaşin, 2009; Dinçer \& Oral, 2013; Şengönül, 2021). Compared to schools that are not disadvantaged, these schools experience even more difficulties in terms of effective learning and teaching opportunities and a lack of family support (Muijs, Harris, Chapman, Stoll \& Russ, 2004; Özcan, Balyer \& Yıldız, 2018).

\section{Curriculum Adaptation and the Affecting Factors}

In the literature, teachers' approaches to curriculum implementation were categorized as curriculum fidelity, curriculum adaptation, and curriculum enactment (Dusenbury, Brannigan, Falco \& Hansen, 2003; Graves, 2008; O’Donnell, 2008; Snyder, Bolin \& Zumwalt, 1992). Dusenbuty et al. (2003, p.240) defined the fidelity to curriculum as "the degree to which teachers and other program providers implement programs as intended by the program developers". As for curriculum adaptation, it is defined as "process whereby adjustments in a curriculum are made by curriculum developers and those who use it in the school or classroom context" (Snyder et al., 1992, p. 410). Snyder et al., (1992, p.152) defined curriculum enactment as "the educational experiences jointly created by students and teacher in the classroom". Fidelity to the curriculum, evaluation of the effectiveness of the curriculum and curriculum materials are important for deciding how they can be improved (Century, Rudnick \& Freeman, 2010), but teachers' fidelity levels to curriculum is affected by various factors (the characteristics and needs of the target population, the budget allocated to the needs of the school, quality of the implementation, teachers' professional competence and characteristics, school opportunities, and the status of current resources etc.) (Burakgazi, 2019; Datnow \& Castellano, 2000; Dusenbury et al., 2003; Öztürk Akar, 2005; Holliday, 2014; Superfine, Marshall \& Kelso, 2015). In Turkey, while Aslan and Erden (2020) reported teachers' high levels of fidelity to curriculum, Burul (2018) stated that although teachers demonstrated high levels of fidelity to the curriculum, they were found to have low mean scores in the "adherence dimension" of the Curriculum Fidelity Scale. Similar studies also reported that teachers had difficulties in ensuring fidelity to curriculum (Bay, Kahramanoğlu, Döş \& Turan-Özpolat, 2017; Dikbayır \& Bümen, 2016). Some studies reported that teachers found the curricula that started to be implemented in 2017 positive, but in the implementation process, they had various difficulties such as inadequacy or lack of textbooks, lack of duration, lack of materials, inappropriate school conditions, and low readiness levels of students (Özcan, Oran \& Arık, 2018; Ural Keleş, 2018)

The factors mentioned above make the implementation of the intended curriculum difficult and require changes. These changes are inevitable for socio-economically disadvantaged schools. While implementing the curriculum, these schools have to cope with more problems compared to schools 
that are not disadvantaged (Dusenbury et al., 2003). Baş and Şentürk (2019) reported that teachers at these schools not only are unable to implement the national curriculum but also have difficulties in adapting it according to the local contexts. Teachers could make some changes in the curriculum to cope with the difficulties they encounter while implementing it (Bümen \& Yazıcılar, 2020; Dikbayır \& Bümen, 2016; Fogo, Reisman \& Breakstone, 2019; Reisman, 2012; Remillard, 2005; Sherin \& Drake, 2009). In this process, contextual differences such as the socio-economic and cultural infrastructure of schools and students have significant effects (Baş \& Şentürk, 2019; Burakgazi, 2019; Burkhauser \& Lesaux, 2017; Graves, 2008; Li \& Harfitt, 2017; 2018; Miller-Day, Pettigrew, Hecht, Shin, Graham \& Krieger, 2013). In fact, teachers' approaches for the implementation of the curriculum and curriculum materials could vary by grade level even in the same school (Troyer, 2019). Kaya, Çetin and Yıldırım (2012) found that teachers implemented curriculum by transforming it at school and grade level considering regional differences, school type, and students' socio-economic levels.

Teachers make adaptations with different preferences (Drake \& Sherin, 2006). Datnow \& Castellano (2000) found that teachers ensured fidelity to practices that they found beneficial for their students rather than personal characteristics such as professional experience, gender, or ethnicity; it was also reported that teachers usually preferred adaptation. Maniates (2010) reported that primary school teachers made adaptations using their pedagogical knowledge to realize the learning objectives of the reading curriculum and enable students to acquire the learning outcomes more fairly. Quinn and Kim (2017) stated that the adaptation made by teachers who have the experience of ensuring fidelity to curriculum was more effective; Burkhauser \& Lesaux (2017) found that all teachers (experienced and inexperienced) made adaptations to meet curriculum standards and students' needs. McCarthey and Woodard (2018) reported that while 12 out of 20 teachers adapted the writing curriculum in line with their students' needs, four teachers ensured fidelity to curriculum, and four teachers did not accept the curriculum. It was found that teachers who ensured fidelity to curriculum had less professional experience and development, and those who made adaptations were experienced and maintained their professional development. Troyer (2019) found that teachers adapted curriculum by benefitting from their previous education experiences and curriculum tendency. Miller-Day et al. (2013) reported that teachers made adaptations due to student needs, professional experiences and personal characteristics, duration of instruction, and institutional and technical limitations. Therefore, it can be stated that instructional context, student, and teacher characteristics are the determinants of curriculum adaptation.
In Turkey, several studies investigated of how curriculum adaptation was realized (Yazıcılar \& Bümen, 2019; Bümen \& Yazıcilar, 2020; Yazıcilar, 2016). However, there seems to be a need for studies focusing on how the adaptation process is realized in socio-demographically disadvantaged schools because related studies also clearly show that sociodemographic and cultural infrastructure has deep effects on curriculum implementation (Bümen et al., 2014, Muijs et al., 2004). In a few studies, the curriculum adaptation process was investigated in schools in rural areas, but a study focusing on the socio-economically disadvantaged school and student context could not be found. Hence, exploration of the difficulties experienced by teachers working in disadvantaged secondary schools in the process of curriculum adaptation, how they cope with the difficulties they encounter, and their views about the ways they realize adaptations are important. While curriculum adaptation has various limitations in its own right (centralistic curriculum structure, teacher autonomy, lack of clear instructions about the adaptation process, etc.) (Bümen \& Yazıcılar, 2020, Gouëdard, Hyttinen, Pont, \& Huan, 2020), it is possible to guess that this process might be more difficult for teachers working in disadvantaged schools. Therefore, this study can contribute to the literature to focus on how teachers working in socio-economically disadvantaged schools manage the adaptation process, the difficulties they experience in implementing and adapting the curriculum, and the quality of the adaptations. This study aims to investigate curriculum adaptation efforts of teachers working in socio-economically disadvantaged secondary schools and their views about the factors affecting these efforts. The curriculum adapted by participants is the revised curriculum that was implemented by the MoNE in 2017 (MoNE, 2017b).

The following research questions were investigated:

1. According to secondary teachers' views, what are the disadvantageousness characteristics of the school they work in?

2. What are the factors affecting teachers' fidelity to curriculum?

3. What are the teachers' adaptation types?

4. What are the difficulties faced by teachers and the solutions they found in the curriculum adaptation process?

\section{Method}

\section{Research Design}

The study used a phenomenological inquiry, which is a qualitative research method. Phenomenology is the investigation of what people experience and how they interpret what they experience (Patton, 1990). The phenomenon at the focus of this study is the curriculum adaptation experiences of teachers who work in socio-economically disadvantaged secondary schools, factors that have effects on this process, and the difficulties they encountered in this experience process. 


\section{Study Group}

The participants included eight female teachers who were selected using the criterion sampling method (Patton, 1990) and agreed to participate in the study. Teachers' professional experience and competence and their curriculum knowledge are one of the variables affecting curriculum adaptation (Baş \& Şentürk, 2019; Dusenbury et al., 2003; Maniates, 2010; McCarthey \& Woodard, 2018; Quinn \& Kim, 2017; Tokgöz, 2013). This study included teachers who continued or graduated from a postgraduate program to see how teachers who continued their professional development benefitted from the knowledge and skills they acquired in the curriculum adaptation process. Hence, the criteria utilized in this study included completing postgraduate education or continuing education in the curriculum and instruction and working in a disadvantaged school in the city. The majority of the teachers who met the criteria were found to work in secondary schools. Therefore, teachers who work in primary school (one first-grade teacher) and high school (one physics teacher) were excluded from the study. Four participants had master's degree; two participants had doctorate degree, and two participants continued their doctorate education. Pre-interviews were conducted with participants to give information about the purpose of the study and receive participant consent. During the pre-interviews, all the teachers reported that they wanted to participate in the study and the schools they worked were mainly in densely populated immigrant-receiving regions including families with low socio-economic level. Two teachers even reported that they were involved in a development project conducted by the governorship of the cities where their schools were located. Interviews were conducted after the participants' informed consent was received. Table 1 demonstrates participants' characteristics. The names used in Table 1 are pseudonyms.
As it is seen in Table 1, three participants had 2-5 years of experience, three teachers had 6-10 years of experience, and two teachers had 15-16 years of experience in the profession. While six participants taught in more than one classroom, two participants taught in one classroom. The class size was between 25 and 38 . Six participants were found to have smart boards and materials related to the course in their classrooms.

\section{Data Collection Tool}

This study utilized standardized open-ended interviews. According to Patton (1990), in the standardized open-ended interview, "the exact wording and sequence of questions are determined in advance. All interviewees are asked the same basic questions in the same order. Questions are worded in a completely open-ended format" (p. 289). In this study, a standardized open-ended interview form prepared by the researcher was utilized to limit the effect of the researcher on the interview process, to collect data more systematically, and to analyze the data easier.

Before the interview form was prepared, the literature was reviewed for current studies (Burkhauser \& Lesaux, 2017; Bümen et al., 2014; Dusenbury et al., 2003; Graves, 2008; Li \& Harfitt, 2017; 2018; Remillard, 2005; Sherin \& Drake, 2009; Tokgöz, 2013; Yazıcılar, 2016). Then questions were written considering components of the curriculum (the objectives, content, learning-instruction process, and assessment and evaluation). Views of four instructors, who held doctorate $(\mathrm{n}=3)$ or master's $(\mathrm{n}=1)$ degree in the curriculum and instruction, and a professor who taught the qualitative research course, were received for the content validity and comprehensibility of the interview form. The questions were revised in line with the views and suggestions indicated by the experts. The first part of the interview form included questions about personal information, and the second

Table 1: Personal Characteristics of the Participants

\begin{tabular}{|c|c|c|c|c|c|c|}
\hline $\begin{array}{l}\text { Pseudo- } \\
\text { names }\end{array}$ & Branches & Experience & $\begin{array}{l}\text { Taught } \\
\text { grades }\end{array}$ & $\begin{array}{l}\text { Experience in } \\
\text { their school }\end{array}$ & $\begin{array}{l}\text { Class } \\
\text { Size }\end{array}$ & Materials in Classrooms \\
\hline Ceren & $\begin{array}{l}\text { Information } \\
\text { Technologies }\end{array}$ & 2 & $5-6$ & 2 & 38 & Smart board \\
\hline Ece & Mathematics & 3 & $5-6-7-8$ & 3 & 30 & $\begin{array}{l}\text { Math blocks, textbook patterns, geometric shapes, } \\
\text { and personal projection }\end{array}$ \\
\hline Pinar & Mathematics & 5 & $5-6-7$ & 3 & 25 & Smart board, textbook \\
\hline Didem & Turkish & 6 & $5-6-7-8$ & 6 & 38 & $\begin{array}{l}\text { Smart board, textbook, workbook, bookshelf, EBA } \\
\text { materials, }\end{array}$ \\
\hline Sevgi & English & 15 & $6-7-8$ & 3 & 33 & $\begin{array}{l}\text { Textbook, workbook, Internet documents, } \\
\text { projection, dictionary, real objects }\end{array}$ \\
\hline Aylin & Science & 8 & $6-8$. & 3 & 32 & $\begin{array}{l}\text { Smart board, textbook, two science labs, lab } \\
\text { supplies }\end{array}$ \\
\hline Fatma & Science & 10 & 8 & 8 & 30 & $\begin{array}{l}\text { Smart board, textbook models, posters, simple } \\
\text { experiment materials }\end{array}$ \\
\hline Sila & Science & 16 & 8 & 6 & 35 & Textbook, board, projection \\
\hline
\end{tabular}


part included questions about the curriculum adaptation process.

\section{Data Collection}

Before the actual implementation, a pilot study was conducted with a teacher who was not a participant. The interview questions and the drilling questions (25 questions) were asked to the participants in the same order (Appendix 1 includes examples of the interview questions). Before the interviews, the participants were informed about the purpose of the study and the ethical rules followed in the study. The interviews were administered in an office environment based on the participants' request. All the interviews were voice-recorded with the participants' consent. The average interview duration was 45 minutes.

\section{Data Analysis}

For data analysis, initially, voice recording was transcribed, and an 88-page document was obtained using Calibri type font and 11 type size. The texts obtained were shared with the participants for confirmation. Data were analyzed using the content analysis technique in NVIVO 10 package programming. Content analysis, which was conducted inductively, initially utilized data-based coding. In other words, no previously prepared code list was utilized. The coding process was used the open coding and axial coding (Merriam, 2013). In the open coding process, each text was read line by line repeatedly and coded as sentences. Then, to obtain categories, all the codes were reread again carefully, and the related codes in terms of meaning were analyzed and interpreted using axial coding. In the axial coding, the codes were repeated by the researcher at different times and the categories that were formed were revised. In addition, the adaptation types found in the literature were utilized to check the consistency of the codes related to the adaptation types with the categories (Bümen \& Yazıcılar, 2020; Burkhauser \& Lesaux, 2017; Li \& Harfitt, 2017; 2018; Miller-Day et al., 2013; Sherin \& Drake, 2009; Yazıcılar, 2016; Yazıcılar \& Bümen, 2019).

The consistency of the codes with the main and subcategories was analyzed by an instructor who was an associate professor specialized in curriculum development. In line with expert recommendations, the "student characteristics" category was combined with the family structure category, and the "students' family structure" category was obtained. This revision was done because the student characteristics were considered to result from family structure (children's working out of school, students' poor health conditions). Similarly, one code in the "disadvantaged school profile" category (terrorist incidents) was removed (since being absent for the past two years). In the "factors affecting fidelity to curriculum" category, two codes in the "factors related to student and family characteristics" sub-category were combined "absence due to students' working out of school", "failure to do homework" and renamed as "students' failing to fulfill their responsibilities due to working out of school". Findings are presented using tables and figures and supported with quotes. Pseudo-names were used for the participant information. Voice recordings obtained in the research process and NVIVO analysis recordings were saved and stored.

\section{FINDINGS}

The findings of this study are presented below.

Secondary School Teachers' Views about the Disadvantageous Characteristics of the School they worked in Table 2 presents findings from secondary school teachers'

Table 2: Findings from Teachers' Views about the Disadvantageous Characteristics of the School they Worked in

\begin{tabular}{|c|c|c|c|}
\hline Main Category & Sub-categories & Codes & $f$ \\
\hline \multirow{13}{*}{$\begin{array}{l}\text { Profile of Disadvantaged } \\
\text { Schools }\end{array}$} & \multirow[t]{8}{*}{ Students' Family Structure } & Low income level & 8 \\
\hline & & Parents' Indifference about school and education & 8 \\
\hline & & Immigrant Families & 6 \\
\hline & & Low parent education level & 6 \\
\hline & & Children's working out of school & 6 \\
\hline & & High number of children & 5 \\
\hline & & Polygamy and fragmented families & 2 \\
\hline & & Students' poor general health condition & 1 \\
\hline & \multirow[t]{2}{*}{ School structure } & Insufficient infrastructure of the school & 6 \\
\hline & & Lack of school counselors & 1 \\
\hline & \multirow[t]{3}{*}{ Social environment structure } & Lack of artistic, cultural, and sports activity areas in the neighborhood & 4 \\
\hline & & Lack of role models & 2 \\
\hline & & Presence of different ethnic groups that are not at peace with each other & 1 \\
\hline
\end{tabular}


views about the disadvantageous characteristics of the schools they worked in.

As it is shown in Table 2, the participants mentioned mostly conditions related to students' family structure among the disadvantageous characteristics of the schools they worked in. Characteristics that described the school and the social structure of the school were mentioned less. All the participants highlighted low income levels of families and indifference of parents about school. In addition, the factors that were frequently mentioned included low parent education level, students' coming from immigrant families that had high number of children, and particularly male students' working out of school. A science teacher, Aylin, described her views supporting these findings.

First of all, most parents are illiterate. In fact, they even do not know which grade their children are enrolled. Some parents look for their children who are enrolled in high school in our school. Families are generally fragmented; either father is in jail or dead or parents are divorced. (...). All of the families in the region I work in are immigrants. The place has a multicultural structure, income level is very low, and children have very low health levels (...). Children have no one that they can see as role models. There are almost no working parents; they live on social aid. (...). There are many children in families, 5-6, 7-8 children, and these children work after school. (...). Polygamy is another issue. (Interview recording, Aylin)

Most of the participants mentioned similar views.

\section{Findings about Factors Affecting Teachers' Fidelity to Curriculum}

Figure 1 demonstrates sub-categories obtained from the views about the factors affecting participants' fidelity to curriculum.

Figure 1 shows that mainly "student and family characteristics" and "curriculum and curriculum materials" were among the factors affecting teachers' fidelity to curriculum. Among the factors related to student and family

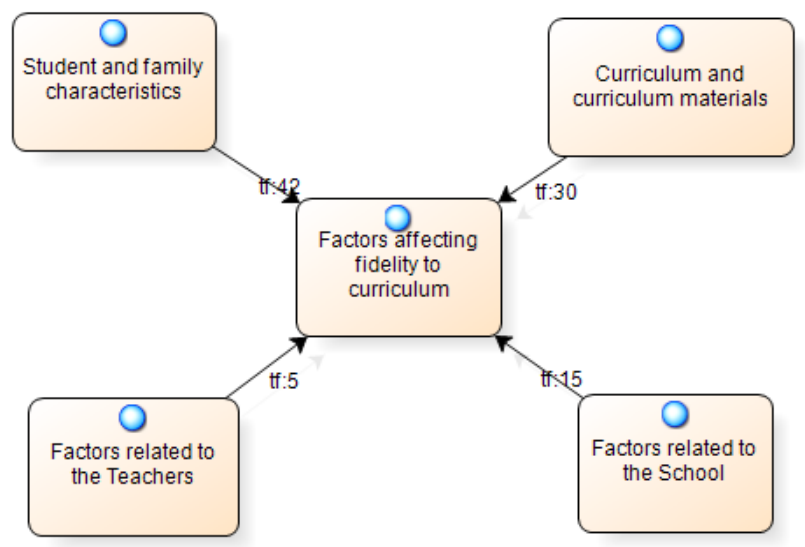

Fig. 1: Sub-categories about the Factors Affecting Teachers' Fidelity to Curriculum. characteristics, "lack of students' prior knowledge and basic skills (reading-writing and basic mathematics), "negative views of families about education" (indifference, lack of cooperation, no permission for group work) were mentioned by all the participants. In addition, "low student motivation, different learning levels, frequent demonstration of disruptive behaviors, inadequate financial income, students' failing to fulfill their responsibilities due to working out of school" were frequently mentioned. Turkish teacher Didem and Mathematics teacher Ece stated their views about students and families:

The biggest problem we had with students who started fifth grade this year was reading and writing. Let's say the child is supposed to write a five-letter word. He is using small letters at the beginning, then capitalizing on the second letter, and writing small letters again in the third letter. (...). Their readiness level is so low, but you have to teach consonant assimilation, terminal devoicing. The child is to take the scholarship exam at the end of the term. I have no other choice but to teach these topics. Okay, I can do it, but the child does not even know the alphabet, he cannot read or write. I show him a letter, he says $O$ for A, (...), it's a big problem at the school I work in (Interview recording, Didem).

I have been in this school for three years; there are students whose parents I have never seen even once. Although I ask them to come to school, tell them that I wanted to see them; some parents do not visit the school or ask about their children's status even in parents' meetings. Some parents do not call back when I call them (...). If parents motivated their children for the courses a little, helped them to become interested, I think the situation would not be so bad. (Interview recording, Ece).

\section{Factors related to Curriculum and Curriculum Materials}

An analysis of Figure 1 shows that the second factor affecting fidelity to curriculum is "curriculum and curriculum materials". Seven participants stated that the objectives, course content, and activities in the curriculum were not appropriate to the students' level in disadvantaged schools. Besides, other factors mentioned included "superficial, insufficient/ inaccurate information in the textbooks, insufficient duration allocated to the topics, insufficiency or lack of materials, lack of guidebooks, and inconsistency between the curriculum components".

While Ceren, a novice teacher who had been working in a disadvantaged school for two years, stated that lack of a textbook on Information Technologies was an important factor affecting fidelity to curriculum, Pinar, a Mathematics teacher and Sila, a science teacher, indicated that lack of guidebooks was a problem. These participants see them as the descriptors of the curriculum. A teacher's view supporting these findings was:

Classes are crowded. As I said before (...) in fact I am telling the same things repeatedly, but the factors include 
lack of laboratories, low success levels of students, students' indifference, and very difficult classroom management. Due to these factors, I cannot implement the curriculum in its original form. When I try to adapt it, I do not have many sources or guidebooks available for me (Interview recording, Ceren).

\section{Factors related to the School and Teachers}

This sub-category included frequently codes such as "lack of physical infrastructure of the school" and "crowded classrooms". Lack of planning in the projects conducted in the school, lack of solutions provided by the administration, teachers' attending courses out of their branch were the factors mentioned by one participant each. Besides, four participants mentioned "teachers' experiencing a feeling of burnout", and one participant reported teachers' frequently changing their working place as a problem. View of an English teacher, Sevgi (15-year experience), was:

Students... actually it may sound like an excuse, but students, unfortunately, have lack of knowledge from previous grades. (...), when I have a fifth-grade student, that system goes more smoothly. This time, the issue of teachers' changing their working place becomes a factor; it ruins when other variables intervene. Unfortunately, my views when I first started this profession have gone through changes as compared to my current views. At first, everything seemed to be more manageable. After some time, that learned helplessness condition starts. You slowly start to think that "Nothing will change no matter what I do, then let's not do anything" (Interview recording, Sevgi).

The participants' views indicate that the context of socioeconomically disadvantaged schools and students could cause teachers to feel weary. It seems that not being able to see the positive outcomes of what they are trying to do and the inability to eliminate the existing limitations with their own efforts cause professional burnout.

\section{Findings of Teachers' Curriculum Adaptation Types}

Figure 2 demonstrates the sub-categories obtained from the participants' views about their curriculum adaptation types.

When Figure 2 is examined, it can be seen that the participants made adaptations mostly by "reorganizing". To adapt to students' level, the participants were found to make changes such as "supplementing, reducing, omitting and completing" regarding the content and activities that were recommended in the curriculum and in the textbooks. Seven participants did not make any adaptations about the objectives, two participants about assessment and evaluation, and one participant about the activities requiring no laboratory work.

Reorganizing: In this category, the participants were found to do reorganizations such as "changing the way activities were conducted, reordering the topics according to students' levels, forming activities and materials about the topics and concepts that are difficult to learn, preparing different assessment tools according to students' level (changing/organizing the questions), detailing the topic to raise cognitive awareness (about socio-cultural issues), designing different activities for students with different learning levels, changing in the education duration, and changing the context of the content".

This study found that most of the participants made adaptations mostly in the content, learning-instruction process (materials, method, techniques, and activities), and assessment and evaluation (reorganized questions according to students' level, prepared their own assessment tools and worksheets). The participants seem to make the reorganization considering the school, social environment, and student characteristics (inclusive education students). Information Technologies teacher, Ceren reported the justification for reorganizing the activities:

I am changing the activities. Every student has attainments to learn, and s/he needs to practice one-to-one in order to learn them. I do not have such a chance; there are 38 students (...). I call some students to practice. They do not have a computer in their house, so they have no chance to practice. I also do not have the chance of giving research assignments and analyzing the product to be submitted to me (Interview recording, Ceren).

Furthermore, while one participant stated that she did reorganization to enhance topic integrity (Since there are many concepts and principles in the science course, I prefer doing organizations or explanations about their place in the whole (Interview recording, Fatma); another participant stated that she did reorganization considering students' socio-cultural characteristics:

For instance, the content demonstrates that kin marriages could cause many genetic diseases in one sentence, but I spent a course hour on this because this is a very common issue in this neighbourhood. I explained puberty as much as that. Unfortunately, our students learn about puberty from their peers rather than their family, which could cause inaccurate

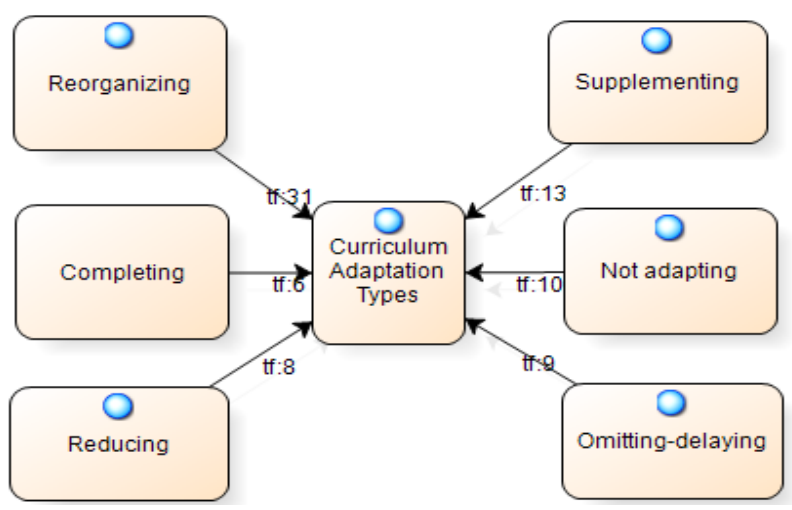

Figure 2: Sub-categories Obtained Related to Teachers' Curriculum Adaptation Types 
information. Therefore, I spent more time teaching in the most accurate way (Interview recording, Sila).

Supplementing: Six participants were found to add information about the concepts in the subject matter (definition, examples, and explanation of the attributes); two participants reported adding examples from real life about principles; four participants reported adding a new topic; and one participant reported adding objectives. Two views supporting this finding were:

The definition of temperature is not given in the presentation of the concept of temperature; I need to give the definition myself. Or if the topic is energy, it says this is energy, but it does not define energy. Hence, I give it and add the definitions. (Interview recording, Aylin).

For instance, there is an activity: what is the expression style of this? The examples should be very clear for the fifth and sixth graders. After listening to the characteristics that I give, the child should be able to say, oh teacher there is this bla bla here, that's why it is argumentative. However, they give such a text that even I cannot be sure about the answer (...). The child could be even more confused if s/he looks at those examples, so I add my own examples (Interview recording, Didem).

Omitting/Delaying: Six participants reported that they omitted the topics and activities that are unfamiliar or difficult to understand for their students; they delayed those topics to some other time (week, month, or year), and two participants stated that they ignored practical assessment activities (project assignments, etc.) and one of them reportedly ignored the objectives that were difficult to realize. One participant's view about this was:

For instance, there is a very complicated example on one page. If they give it at the very beginning, I say I will skip it and solve it later. Usually, there are no problems, they all say okay. (...). Sometimes when I say "Children, this example is a little higher than your level, they say no it is not. They say "let's try and see, we can skip if we cannot solve". We decide together (Interview recording, Pinar).

Reducing/simplification: The participants stated that they simplified and reduced the information and activities (number of examples, number of questions) considering their students' characteristics. One participant stated that the school and classroom conditions were not appropriate and students had low learning levels and indicated the following views:

I only do demonstration experiments. Then I accelerate the process by reducing the number of questions and the number of examples required to be solved in each topic (Interview recording, Sila).

Completing: Six participants reported making adaptation to complete lack of information about student's prior knowledge. One participant mentioned the adaptation she made for completing students' prior knowledge as follows.
The first topic of 7th graders is multiplication and division in whole numbers. However, students forget addition and subtraction after the summer holiday; I start from the beginning. I start with addition and subtraction, which are sixth-grade topics. We spend 2-3 weeks on these topics and then move to multiplication and division. I even do it in each lesson, which is problematic in terms of time management (Interview recording, Ece).

\section{Findings about the Difficulties Faced by Teachers in Curriculum Adaptation and the Solutions They Found}

Table 3 demonstrates findings about difficulties faced by teachers in curriculum adaptation and the solutions they found.

As it is seen in Table 3, difficulties faced by teachers in the curriculum adaptation were categorized as "difficulties in planning the instruction process" and "difficulties in organizing and presenting the content". All the participants stated that they did not reflect the adaptations they did in the annual plan; they reportedly realized those adaptations implicitly or spontaneously. Only one mathematics teacher reported that she prepared daily plans and showed the changes she made there.

We are preparing annual plans with group teachers by benefiting from the curriculum; I do not make changes there. However, I change in the daily plan (Researcher: Do you prepare daily plans?) Yes; I prepare daily plans and change in the daily plans. I put my own activities and materials like worksheets. I write the questions I ask according to students' characteristics (they have low level), living conditions, activities, examples I gave, and assignments (Interview recording, Pinar).

Four participants reported that they informed students about the new regulations/revisions before or during the lesson; two participants reportedly made no explanations, and one participant indicated that she informed students when she made changes in exam topics in eight-grade.

Four participants reported that when they added a new activity or information to the content or did reorganization according to students' level, they had difficulties in arranging the duration of instruction and preparing an effective individual education plan. Two participants stated that they had difficulties while deciding whether adaptation was appropriate or not.

In the organization and presentation of the content, the participants were found to have difficulties in organizing the topics according to class and student level, teaching difficult topics, determining the boundaries of the content adapted, and using a different method and activity. One participant (Aylin) stated that she could not be sure about the necessity of the adaptation when there was a conflict between the added information and the information in the textbook. One participant's views about this are as follows: 
Table 3: The Categories and Codes about the Difficulties Faced by Teachers in Curriculum Adaptation and the Solutions They Found

\begin{tabular}{|c|c|c|c|}
\hline Main Category & Sub-categories & Codes & $f$ \\
\hline \multirow{19}{*}{$\begin{array}{l}\text { Difficulties encountered in } \\
\text { curriculum adaptation and } \\
\text { solutions }\end{array}$} & \multirow{6}{*}{$\begin{array}{l}\text { Difficulties in planning the instruction process } \\
\text { Arranging the instruction duration } \\
\text { Preparing an effective individual education plan } \\
\text { Deciding on the appropriateness of the adaptation }\end{array}$} & Failing to reflect the adaptations in the & 8 \\
\hline & & annual plan & \\
\hline & & & \\
\hline & & 4 & \\
\hline & & 4 & \\
\hline & & 2 & \\
\hline & Difficulties in organizing and presenting the content & $\begin{array}{l}\text { Organizing / presenting the topics according } \\
\text { to the classroom and student level }\end{array}$ & 2 \\
\hline & Teaching difficult topics & 2 & \\
\hline & Determining the borders of the adapted content & 2 & \\
\hline & Using a different method/activity & 2 & \\
\hline & \multirow[t]{2}{*}{ Not being sure about adding new information to the content } & 2 & \\
\hline & & 1 & \\
\hline & Other & $\begin{array}{l}\text { Having difficulties in preparing a different } \\
\text { assessment tool }\end{array}$ & 1 \\
\hline & \multicolumn{2}{|c|}{ Using information obtained in postgraduate education } & 8 \\
\hline & \multicolumn{2}{|l|}{ Collaborating with colleagues } & 7 \\
\hline & \multicolumn{2}{|c|}{ Benefiting from internet sources and views in forums and blogs } & 6 \\
\hline & \multicolumn{2}{|c|}{ Receiving views of instructors at university } & 4 \\
\hline & \multicolumn{2}{|l|}{ Benefiting from professional books } & 2 \\
\hline & \multicolumn{2}{|l|}{ Benefiting from in-service trainings } & 1 \\
\hline
\end{tabular}

I do not think that I am fully qualified about which topics should be instructed according to students' level. I think this should be prepared and done by people who have a higher education level (...). I do not know which topics to add and according to which topics I will do adaptations, I cannot decide. I experience conflict when I think about the topics and look at the student profile. In fact, I also do not know how to arrange them. I have great difficulties (Interview recording, Ceren).

As it is seen in Table 3, the participants stated that they mainly found solutions such as consulting the information they gained in the postgraduate education courses, collaborating with their colleagues, benefitting from internet sources and views in forums and blogs, and instructors at the university. Only one participant stated that she benefitted from the information gained from in-service trainings.

\section{Discussion}

Teachers are at the focus of the curriculum development process as well as instruction. As highlighted by Bruner (2009, p.xi) "the curriculum is for teachers rather than students ..." because a strong and transformative interaction between the teacher and curriculum affects what and how students learn (Fogo et al., 2019; Troyer, 2019).

This study indicated four main findings regarding the curriculum adaptation efforts of teachers working in socioeconomically disadvantaged schools: a) Students' family structure is the main factor determining disadvantageousness in socio-economically disadvantaged schools. b) Student and family characteristics, curriculum and curriculum materials are the factors that frequently prevent fidelity to curriculum. c) Teachers made adaptations such as reorganizing, supplementing, omitting/delaying, and reducing/simplification, completing. d) In the adaptation process, teachers were found to experience difficulties associated with planning the instruction process and organizing and presenting the content. The findings obtained are discussed below.

Most of the participants in this study stated that factors about "students' family structure" caused disadvantageousness for the schools they worked in. Factors such as low income level of families, indifference about school and education, being immigrants, low education level, and students' working out of school formed socio-economic disadvantageousness for students and schools. Studies show that socio-economically disadvantaged schools in cities have similar family and student profiles (Eryavaş, 2009; Özcan, Balyer \& Yıldız, 2018; Şengönül, 2021). Özbaş (2018) stated that in the schools that had disadvantaged sociological stratum, $56 \%$ of mothers were not even graduates of primary school; $60 \%$ of fathers graduated from primary school; the majority of the families had lack of social security; and they did not see primary education as a need. Similarly, the participants mentioned the insufficiency of the physical infrastructure of the school and social environment conditions as disadvantageousness. Aydın, Selvitopu and Kaya (2018) stated that while instruction materials were at a sufficient level in successful OECD 
countries, they were reported to be insufficient in schools with a low socioeconomic level in Turkey. Moreover, lack of activity areas and role models in the social environment where the schools are located indicate that these students were deprived of positive social environment support. Negative family, school, and social environment conditions could affect students' school success negatively. However, these negative effects cannot be generalized to all disadvantaged students because there could be students who have a socio-economically disadvantaged background but high school success and academic resilience (Dinçer \& Oral, 2013; Fındık \& Kavak, 2013; OECD, 2011).

Disadvantaged students who attended socio-economically disadvantaged schools are reported to be two times more likely to demonstrate low performance and experience more inequality (OECD, 2018). This study found that teachers who worked in socio-economically disadvantaged secondary schools did not show fidelity to curriculum due to negative factors, such as student characteristics and family structure, curriculum and curriculum materials, and school structure. This study showed that both experienced and novice teachers highlighted the high number of students who had inadequate basic skills and frequently showed disruptive behaviors, parents' indifference, and low income level among the factors associated with student and family structure. Besides, the inappropriateness of the objectives, topics and activities in the curriculum to student level, insufficiencies in the textbooks, and lack of duration were frequently mentioned among the factors related to curriculum and curriculum materials.

It can be stated that these factors were both prevented fidelity to curriculum and made adaptation difficult. Fidelity to curriculum was affected by many factors, such as the characteristics of the target population, conditions of the schools where the curriculum was implemented, nature of the implementation, and the support provided (Holliday, 2014). This study also indicates that fidelity to curriculum is affected by the characteristics of the target population, curriculum structure, and the conditions where the curriculum is implemented. Similar studies reported that teachers were not so competent about implementing the intended curriculum in terms of different school, classroom, and student characteristics (Baş \& Şentürk, 2019; Bay et al., 2017; Burul, 2018; Bümen \& Yazıcilar, 2020; Tokgöz, 2013). Negative conditions mentioned could negatively affect students' acquisition of the targeted learning outcomes effectively and productively. Gouëdard et al., (2020) stated that fidelity to curriculum prepared by centralised system limited teacher autonomy and ignored contextual factors. They also reported that curriculum implementation should adopt an adaptation approach rather than a fidelity approach.

In this study, experienced and some of the novice teachers stated that feelings of burnout experienced by teachers in disadvantaged secondary schools and teacher changing their working place as important problems. This finding is also supported by the results reported by Tosun, Ay and Koçak (2000). Three participants who had the first five years of experience reported that due to the difficulties of working in disadvantaged schools and being novice in the profession, they had difficulties in ensuring fidelity to curriculum and making curriculum adaptation; they also reported that they actually could not make adaptations. According to the Teaching and Learning International Survey [TALIS] (2018), in Turkey, $40,4 \%$ of novice teachers worked in disadvantaged schools; this proportion was $22,2 \%$ in OECD average (TEDMEM, 2020). Teaching experience and the quality of this experience are factors that determine the success of the instructional curriculum in practice and positively affect students' learning (Burkhauser \& Lesaux, 2017; McCarthey \& Woodard, 2018; Quinn \& Kim, 2017, Troyer, 2019). However, if the context where the curriculum is implemented does not enable fidelity to curriculum, teachers cannot acquire this experience. Particularly adaptation efforts of novice teachers or inability to make adaptations could also prevent the benefit expected from the curriculum.

This study found that teachers made adaptation mostly through reorganizing. In addition, they performed, supplementing, omitting/delaying, completing and reducing/ simplification. The participants also frequently highlighted changes such as changing the way activities, reorganizing the topics according to students' level, preparing materials for the students who have difficulties, preparing different assessment tools appropriate to students' level, and detailing the topic to raise cognitive awareness. It was found that the participants omitted or reduced/simplified the topics and activities that they considered inappropriate to the student level. Most of the participants were found to add information about the concepts to generate prior knowledge and ensure topic integrity. This study found that the participants made adaptations considering mainly school, social environment, family, and student characteristics, and the adaptations demonstrated variety, and they did the adaptations mainly about content, learninginstruction process, and assessment and evaluation tools. Similarly, Miller-Day et al. (2013) reported that teachers mainly made adaptations such as ignoring partially or completely, adding and reviewing, changing out-of-class activities as in-class activities, changing group activities as individual activities, changing the materials, and adding duration. Li and Harfitt $(2017 ; 2018)$ reported that teachers made adaptations such as adjusting, replacing and revising, supplementing and omitting, and inventing in the curriculum materials. Yazıcilar (2016) found that teachers made adaptations such as "omitting, creating, and changing with a new one, making changes in duration, covering superficially, using different sources/ materials, and these adaptations were mainly related to content 
and duration. The adaptation types determined in this study yielded similar results with earlier studies (Burkhauser \& Lesaux, 2017; Bümen \& Yazıcılar, 2020; Drake \& Sherin, 2006; Fogo et al., 2019; Sherin \& Drake, 2009; Troyer, 2019; Yazıcilar \& Bümen, 2019). As a result, teachers seem to frequently make changes in the activities recommended in the curriculum considering students' knowledge level and school conditions to eliminate inadequacies in students' prior knowledge and make understanding easier.

Teachers can make adaptations by being affected by the curriculum structure, perceptions about curriculum and profession, experiences, school context, nature of the information, families, and administration forces (administrators, inspectors) (Tokgöz, 2013). This study showed that student characteristics and school context were the determinant factors. In other words, the characteristics of socio-demographically disadvantaged students and schools formed the context of adaptation. Considering student characteristics in adaptation is also reported in similar studies. For instance, teachers are reported to make adaptations to improve deep conceptual understanding and eliminate misunderstandings (Drake \& Sherin, 2006), meet students' needs and inadequacies about understanding and content, eliminating the insufficiencies (Fogo et al., 2019); enhance students' understanding of abstract concepts and active participation (Maniates, 2017); and complete students' lack of information and bring them to a determined learning level (Yazıcilar, 2016). Student-related factors are not issues that can be solved or eliminated by curriculum development experts alone. However, it is possible to design curriculum materials to be used by teachers considering disadvantaged schools and students in the local context. In this process, it is self-evident that textbooks are not sufficient alone. Particularly novice teachers indicated that they needed guidebooks.

This study found that the difficulties experienced by the participants in the curriculum adaptation were mainly associated with planning the instruction process, and organizing and presenting the content. It is possible to say that the participants made adaptations implicitly and generally extemporarily during instruction, without reflecting the changes in the annual plans due to legal responsibilities. Teachers' adaptations could happen before, during, and after instruction (Drake \& Sherin, 2006). This study found that even if teachers made a mental plan beforehand, they did not put it in writing and generally decided on the adaptations during instruction. Only one participant stated that she reflected on the changes she made in the daily plan. This finding is similar to the results reported by Yazıcilar (2016). As teachers did not reflect the adaptations they made in their instruction plans, there is a disconnection between the plan and practice, indicating the difficulty of determining the difference between the attainments to be acquired by students and the attainments observed. Also, some of the participants were found to have difficulties in arranging the duration of instruction and preparing an effective individual education plan. As for organizing and presenting the content, the participants were found to have difficulties mainly in adding and reorganizing. This finding is similar to the results reported by Li and Harfitt (2017). This study showed that for the difficulties they experienced, the participants found solutions such as benefiting from the knowledge they gained from postgraduate courses, collaborating with their colleagues, benefitting from internet sources, forums, and blogs, and asking opinions of instructors at the university.

This study involved teachers who completed or continued postgraduate education in the field of education programs and instruction. Hence, it was possible to have an idea about the participants' conditions about benefitting from the knowledge and skills acquired about curriculum and instruction. All the participants stated that they benefitted from their postgraduate experience in the curriculum adaptation process. In addition to the difficulties caused by working in socio-demographically disadvantaged schools, teachers' maintaining professional development indicates their increased efforts for curriculum adaptation. Hence, teachers who benefit from professional development opportunities are reported to make more consistent adaptations (McCarthey \& Woodard, 2018). Aktan (2020) found that teachers preferred postgraduate education to enhance personal and professional development. The participants reported that they pursued their postgraduate education due to similar thoughts, but they also indicated that they had postgraduate education in order not to experience professional burnout in the schools they worked. Participants' efforts could help them to provide their students with more qualified cognitive and affective support. Cognitive and affective support provided by teachers to socio-economically disadvantaged students is reported to have positive effects on their academic achievement (Özberk, Fındık \& Özberk, 2018). Teachers working in these schools could make adaptations using effective learning and instruction strategies to cope with various difficulties, to increase students' achievement and basic academic skills, and to support the learning of students with academic resilience (Fındık \& Kavak, 2013; Karabağ-Köse, 2019; OECD, 2012; 2018). The participants seem to acquire this knowledge and skills more effectively in postgraduate education. However, we cannot state that all teachers working in these schools have postgraduate education experience. Hence, as of 2018, the proportion of teachers with a postgraduate degree was reported to be $17.67 \%$ for master's degree and $0.18 \%$ for doctorate degree (Ceylan, Özdogan Özbal, Sever, \& Boyacı, 2020). McCarthey and Woodard (2018) reported that professional development opportunities were limited in rural areas, and teachers struggled alone to create significant 
activities in the adaptation process. Therefore, teachers' instructional competence should be strengthened to create a balance between fidelity to curriculum and adaptation and prevent inconsistencies (Maniates, 2010). If teachers are provided with the support they need while making adaptations, more successful adaptations could be achieved through mutual collaboration (Dusenbury et al., 2003). Drayton, Bernstein, Schunn and McKenney (2020) found that collaboration with teachers in the adaptation process enabled more effective adaptations through innovative materials developed by designers without harming the core of the curriculum.

\section{ConcLusion}

This study found that the participants made adaptations in the content, learning-teaching process, and assessment and evaluation tools to meet the needs specific to the students in socio-economically disadvantaged secondary schools. However, this study did not investigate the appropriateness of adaptations for the purposes of the curriculum. The adaptation process should be investigated as a whole and its effect on student learning should be identified to decide on the appropriateness of adaptations. Too many adaptations could both prevent fidelity to curriculum and make the determination of the real effect of curriculum difficult (Dusenbury et al., 2003; Holiday, 2014). More harmful outcomes could be obtained if adaptations do not serve instruction objectives (Bümen \& Yazıcılar, 2020). Hence, teachers working in socio-economically disadvantaged secondary schools do not demonstrate complete fidelity to curriculum and have difficulties in adapting it. More concrete instructions are needed to make the adaptation process in these schools consistent with the objectives of curriculum. Reisman (2012) recommends that comprehensive materials that can be implemented by teachers easily should be prepared and they should be opened to teachers' access, and there should be concrete instructions about how to use domainspecific strategies. However, as reported by Bümen et al. (2014), there are no clear instructions and authorizations in Turkey about how teachers can make adaptations. Although the MoNE (2017b) stated that teachers could be flexible in preparing and implementing teaching activities in line with the students' individual differences, interests, and needs and expectations, there seems to be a need for more concrete and clear instructions.

\section{Suggestion}

Based on the findings from this study, it could be recommended to provide interventions for eliminating disadvantageousness initially in schools where disadvantageous students are enrolled (increasing parent involvement and awareness, providing financial support, focusing on effective learning and teaching strategies, creating a positive school culture) (Charalambousa, Kyriakides, \& Creemers, 2018; Findık ve Kavak, 2013; OECD, 2012; Muijs et al., 2004).

Families' awareness about the importance of education could be improved particularly by preparing family education programs.

-Instructions could be prepared about how and in what situations adaptations need to be made while developing curriculum; curriculum materials could be developed (for example guidebooks); and professional development opportunities could be increased.

Experimental, design-oriented, or action research could be conducted to determine the nature of adaptations in socioeconomically disadvantaged schools.

\section{Limitation}

This study investigated the curriculum adaptation efforts and adaptation types of teachers from different branches working in socio-economically disadvantaged schools through interviews. An important limitation of the study is that it utilized a single data collection tool, and the data were based on personal reports. Seven out of eight participants stated that they did not prepare daily lesson plans, and they reportedly did not reflect the adaptations they made in the annual plan, so lesson plans were not used. In addition, since the purpose was to determine the common points during curriculum adaptation rather than the adaptation made in a unit, no recordings were made for a specific unit. Hence, findings obtained in this study are limited to only eight participants and do not aim to make generalizations. Besides, adaptation types obtained in this study are based on teachers' self-explanations. Therefore, adaptations done in the classroom could show differences and might be more than indicated (Miller-Day et al., 2013).

\section{References}

Aktan, O. (2020). Öğretmenlerin kariyer gelişimi açısından lisansüstü eğitimin değerlendirilmesi. Journal of Higher Education and Science, 10(3), 596-607. doi:10.5961/jhes.2020.419

Aslan, M. \& Erden, R. Z. Ortaokul öğretmenlerinin öğretim programına bağlılıklarının incelenmesi. Yüzüncü Yıl Üniversitesi Eğitim Fakültesi Dergisi, 17(1), 175-199. doi:10.33711/ yyuefd.691525

Aydın, A., Sarıer, Y. \& Uysal, Ş. (2012). The comparative assessment of the results of PISA mathematical literacy in terms of socioeconomic and socio-cultural variables. Education \& Science, 37, 164.

Aydın, A., Selvitopu, A. \& Kaya, M. (2018). Resources invested in education and PISA 2015 results: a comparative study. Elementary Education Online, 17(3), 1283-1301. doi: 10.17051/ ilkonline.2018.466346

Baş, G. \& Şentürk, C. (2019). Teaching-learning conceptions and curriculum fidelity: A relational research. International Journal of Curriculum and Instruction, 11(2), 163-180. 
Bay, E., Kahramanoğlu, R., Döş, B. \& Turan-Özpolat, E. (2017). Programa bağııı̆ı etkileyen faktörlerin analizi. Mehmet Akif Ersoy Üniversitesi Eğitim Fakültesi Dergisi, 43, 110-137.

Burakgazi, S. (2019). Programa bağlılık: Kara kutuyu aralamak. Başkent University Journal of Education, 6(2), 236-249.

Burkhauser, M. A. \& Lesaux, N. K. (2017). Exercising a bounded autonomy: Novice and experienced teachers' adaptations to curriculum materials in an age of accountability. Journal of Curriculum Studies, 49(3), 291-312. doi:10.1080/00220272.2 015.1088065

Burul, C. (2018). Öğretmenlerin eğitim programı tasarım yaklaşımı tercihlerinin öğretim programına bağlllıklarıyla olan ilişkisinin incelenmesi. Unpublished master's thesis, Balıkesir Üniversitesi Sosyal Bilimler Enstitüsü, Balıkesir.

Bruner, J. (2009). Eğitim Süreci 1st ed. (Çev. Talip Öztürk). Ankara: Pegem Akademi Yayınları. Orijinal Basım Yılı (1979).

Bümen, N. T., Çakar, E. \& Yıldız, D. G. (2014). Türkiye’de öğretim programına bağlılık ve bağlılığı etkileyen etkenler. Kuram ve Uygulamada Eğitim Bilimleri, 14(1), 203-228.

Bümen, N. T. \& Yazıcılar, Ü. (2020). Öğretmenlerin öğretim programı uyarlamaları üzerine bir durum çalışması: Devlet ve özel lise farklılıkları. Gazi University Journal of Gazi Educational Faculty, 40(1), 183-224.

Caillods, F. (1998). Education strategies for disadvantaged groups: Some basic ideas. IIEP Contributions: No. 31. UNESCO/ International Institute for Educational Planning, Paris.

Century, J., Rudnick, M. \& Freeman, C. (2010). A framework for measuring fidelity of implementation: A foundation for shared language and accumulation of knowledge. American Journal of Evaluation, 31(2) 199-218. doi: 10.1177/1098214010366173

Ceylan, E., Özdogan Özbal, E., Sever, M. \& Boyac1, A. (2020). Türkiye' deki öğretmen ve okul yöneticilerinin görüşleri, öğretim koşulları: TALIS 2018 öğretmen ve okul yöneticileri yanıtları analizi. Ankara: Millî Egitim Bakanlığı Yayınları.

Chakraborty, K. \& Harper, R. K. (2017). Measuring the impact of socio-economic factors on school efficiency in Australia. Atlantic Economic Journal, 45(2), 163-179. doi: 10.1007/s11293017-9542-X

Charalambousa, E., Kyriakidesa, L. \& Creemers, B. P. M. (2018). Promoting quality and equity in socially disadvantaged schools: A group-randomisation study. Studies in Educational Evaluation, 57, 42-52. doi:10.1016/j.stueduc.2016.06.001

Datnow, A. \& Castellano, M. (2000). Teachers' responses to success for all: How beliefs, experiences, and adaptations shape implementation. American Educational Research Journal, 37(3), 775-799. doi:10.3102/00028312037003775

Chernysh V. Valentyna; Zadorina Olha; Melnyk Kateryna; Khromova I. Olga; Danyliuk M. Mykola. "Development of professional competence of present and future teachers under the conditions of transformational processes in education". Journal for Educators, Teachers and Trainers, 11, 1, 2020, 56-67. doi: 10.47750/jett.2020.11.01.006

Dikbayır, A. \& Bümen, N. T. (2016). Dokuzuncu sınıf matematik dersi öğretim programına bağlılığın incelenmesi. Uluslararası Ĕ̆itim Programları ve Öğretim Çalışmaları Dergisi, 6(11), 17-38.

Dinçer, M. A. \& Kolaşin, G. U. (2009). Türkiye’de öğrenci başarısızlı̆̆ında eşitsizliğin belirleyicileri. İstanbul: Eğitim Reformu Girişimi yayınları. Retrieved March 16 2021, https://www.egitimreformugirisimi.org/yayin/turkiyedeogrenci-basarisinda-esitsizligin-belirleyicileri/

Dinçer, M. A. \& Oral, I. (2013). Türkiye'de devlet liselerinde akademik dirençlilik profili. İstanbul: Eğitim Reformu Girişimi yayınları.

Drake, C. \& Sherin, M. G. (2006). Practicing change: Curriculum adaptation and teacher narrative in the context of mathematics education reform. Curriculum Inquiry, 36(2), 153-187. URL: https://www.jstor.org/stable/3698503

Drayton, B., Bernstein, D., Schunn, C. \& McKenney, S. (2020). Consequences of curricular adaptation strategies for implementation at scale. Science Education, 104, 983-1007. doi: 10.1002/sce.21595

Dusenbury, L., Brannigan, R., Falco, M. \& Hansen, W. B (2003). A review of research on fidelity of implementation: implications for drug abuse prevention in school settings. Health Education Research: Theory \& Practice, 18(2), 237-256.

Eryavaş, Ö. (2009). Gecekondu alanlarının dönüşümü: Ankara Gültepe Mahallesi örneği. Unpublished master's thesis, Ankara Üniversitesi Sosyal Bilimler Enstitüsü, Ankara.

Fındık, L. Y. \& Kavak, Y. (2013). Türkiye'deki sosyo-ekonomik açıdan dezavantajlı öğrencilerin PISA 2009 başarılarının değerlendirilmesi. Educational Administration: Theory and Practice, 19(2), 249-273.

Fogo, B., Reisman, A. \& Breakstone, J. (2019) Teacher adaptation of document-based history curricula: Results of the reading like a historian curriculum-use survey. Journal of Curriculum Studies, 51(1), 62-83. doi: 10.1080/00220272.2018.1550586

Gouëdard, P., Hyttinen, S., Pont, B. \& Huan, P. (2020). Curriculum reform: A literature review to support effective implementation. Education Working Papers, no. 239. doi:10.1787/efe8a48c-en

Graves, K. (2008). The language curriculum: A social contextual perspective. Language Teaching, 41(2), 147-181. doi:10.1017/ S0261444807004867

Holliday, L. R. (2014). Using logic model mapping to evaluate program fidelity. Studies in Educational Evaluation, 42, 109-117. doi:10.1016/j.stueduc.2014.04.001

Karabağ-Köse, E. (2019). Examining the factors affecting the school engagement of at-risk students attending disadvantaged schools. Education \& Science, 44(199). doi: 10.15390/ EB.2019.7893

Kaya, E., Çetin, P. S. \& Yıldırım, A. (2012). Transformation of centralized curriculum into classroom practice: An analysis of teachers' experiences. International Journal of Curriculum and Instructional Studies, 2(3), 103-113.

Li, Z. \& Harfitt, G. J. (2017). An examination of language teachers' enactment of curriculum materials in the context of a centralised curriculum. Pedagogy, Culture \& Society, 25(3), 403-416. doi:10.1080/14681366.2016.1270987

Li, Z. \& Harfitt, G. J. (2018). Understanding language teachers' enactment of content through the use of centralized curriculum materials. Asia-Pacific Journal of Teacher Education, 46(5), 461-477. doi: 10.1080/1359866X.2017.1351918

Maniates, H. (2010). When highly qualified teachers use prescriptive curriculum: Tensions between fidelity and adaptation to local contexts. Unpublished doctorate dissertation, University of California, Berkeley.

McCarthey, S. J. \& Woodard, R. (2018). Faithfully following, adapting, or rejecting mandated curriculum: Teachers' curricular enactments in elementary writing instruction. 
Pedagogies: An International Journal. 13(1), 56-80. doi: 10.1080/1554480X.2017.1376672

Merriam, S. B. (2013). Qualitative research: A guide to design and implementation [Nitel araştırma: Desen ve uygulama için bir rehber] (S. Turan, Trans. Ed., 3rd ed.). Ankara: Nobel Yayın Dağıtım.

Ministry of National Education [MoNE]. (2017a). Akademik becerilerin izlenmesi ve değerlendirilmesi (ABİDE) 20168. siniflar raporu. Retrieved from 9 March 2021, https://odsgm. meb.gov.tr/meb_iys_dosyalar/2017_11/30114819_iY-web-v6. pdf

Ministry of National Education [MoNE] (2017b). Müfredatta yenileme ve değişiklik çalışmalarımız üzerine.... Ankara: Talim ve Terbiye Kurulu Başkanlığı. Retrieved from 13 March 2018, https://ttkb.meb.gov.tr/meb_iys_dosyalar.

Miller-Day, M., Pettigrew, J., Hecht, M. L. Shin, Y., Graham, J. \& Krieger, J. (2013). How prevention curricula are taught under real-world conditions: Types of and reasons for teacher curriculum adaptations. Health Education, 113(4), 324-344. doi:10.1108/09654281311329259

Muijs, D., Harris, A., Chapman, C., Stoll, L. \& Russ, J. (2004). Improving schools in socioeconomically disadvantaged areas-a review of research evidence. School Effectiveness and School Improvement, 15(2), 149-175. doi:10.1076/sesi.15.2.149.30433

O'Donnell, C. L. (2008). Its relationship to outcomes in K -12 Curriculum intervention research defining, conceptualizing, and measuring fidelity of implementation and its relationship to outcomes in K-12 curriculum intervention research. Review of Educational Research, 78, 33. doi: 10.3102/0034654307313793

OECD. (2011). Against the odds: Disadvantaged Students Who Succeed in School. OECD Publishing. doi:10.1787/9789264090873-en

OECD. (2012). Equity and qualityeducation-Supporting disadvantaged students and schools. Executive Summary. OECD Publishing. Paris: OECD.doi:10.1787/9789264130852-en

OECD. (2018). Are disadvantaged students affected by the socioeconomic profile of their school? in Equity in Education: Breaking Down Barriers to Social Mobility. OECD Publishing, Paris. doi:10.1787/9789264073234-7-en

Özbaş, M. (2018). Dezavantajlı sosyolojik tabakalarda zorunlu eğitim sürecini etkileyen değişkenler. Kastamonu Education Journal, 26(4), 1143-1154. doi:10.24106/kefdergi.434262

Öztürk Akar, E. (2005). Lise biyoloji dersi öğretim programının uygulanmasında okul düzeyinde görülen farklılıklar. Eğitim Bilimleri ve Uygulama, 4(7), 51-67.

Özcan, K., Balyer, A. \& Yıldız, A. (2018). Ekonomik olarak dezavantajlı bölgelerde görev yapan ortaokul müdürlerinin liderlik davranışları. Mersin Üniversitesi Eğitim Fakültesi Dergisi, 14(2), 532-547

Özcan, H., Oran, Ş. \& Arık, S. (2018). Fen bilimleri dersi 2013 ve 2017 öğretim programlarının öğretmen görüşlerine göre karşılaştırmalı incelenmesi. Başkent University Journal of Education, 5(2), 156-166.

Patton, M.Q. (1990). Qualitative evaluation and research methods (2nd ed.). Newbury Park, CA: Sage Publications.

Quinn, D. M. \& Kim, J. S. (2017). Scaffolding fidelity and adaptation in educational program implementation: Experimental evidence from a literacy intervention. American Educational Research Journal, 54(6) 1187-1220. doi: 10.3102/0002831217717692

Reisman, A. (2012) Reading like a historian: A document-based history curriculum intervention in urban high schools. Cognition and Instruction, 30(1), 86-112. doi:10.1080/073700 08.2011.634081

Remillard, J. T. (2005). Examining key concepts in research on teachers' use of mathematics curricula. Review of Educational Research, 75(2), 211-246.

Shawer, S. F. (2010). Classroom-level curriculum development: EFL teachers as curriculum-developers, curriculum-makers and curriculum-transmitters. Teaching and Teacher Education, 26, 173-184. doi:10.1016/j.tate.2009.03.015

Sherin, M. G. \& Drake, C. (2009) Curriculum strategy framework: investigating patterns in teachers' use of a reform-based elementary mathematics curriculum. Journal of Curriculum Studies, 41(4), 467-500.doi:10.1080/00220270802696115

Snyder, J., Bolin, F. \& Zumwalt, K. (1992). Curriculum implementation. In P.W. Jackson (Ed.), Handbook of research on curriculum, (pp. 402-435). New York: Macmillan.

Superfine, A. C., Marshall, A. M. \& Kelso, C. (2015). Fidelity of implementation: Bringing written curriculum materials into the equation. The Curriculum Journal, 26(1), 164-191. doi: 10.1080/09585176.2014.990910.

Şengönül, T. (2021). The adverse role of poverty in the socialization processes in the family and in the cognitive development of children and school performance. Pegem Journal of Education and Instruction, 11(2), 01-13. doi: 10.14527/pegegog.2021.00

Şirin, S. R. (2005). Socioeconomic status and academic achievement: A meta analytic review of research. Review of Educational Research, 75, 417-453. doi: 10.1080/00220272.2017.1407458

TEDMEM. (2020). 2019 eğitim değerlendirme raporu (TEDMEM Değerlendirme Dizisi 6). Ankara: Türk Eğitim Derneği.

Tokgöz, Ö. (2013). Transformation of centralized curriculum into teaching and learning processes: Teachers' journey of thought curriculum into enacted one. Unpublished doctorate dissertation, Ortadoğu Teknik Üniversitesi Sosyal Bilimler Enstitüsü, Ankara.

Tosun, A., Ay, M. H. \& Koçak, S. (2020). Yönetici gözüyle dezavantajlı okullar: sosyal adaletin sağlanması için çözüm önerileri. Journal of Qualitative Research in Education, 8(3), 980-999. doi:10.14689/issn.2148-2624.1.8c.3s.9m

Troyer, M. (2019) Teachers' adaptations to and orientations towards an adolescent literacy curriculum. Journal of Curriculum Studies, 51(2), 202-228. doi:10.1080/00220272.2017.1407458

Ural Keleş, P. (2018). 2017 Fen bilimleri dersi öğretim programı hakkında beşinci sınıf fen bilimleri öğretmenlerinin görüşleri. Journal of Qualitative Research in Education, 6(3), 121-142. doi:10.14689/issn.2148-2624.1.6c3s6m

Yazıcılar, Ü. (2016). Öğretmenlerin matematik dersi öğretim programını uyarlama sürecinin incelenmesi. Unpublished master's thesis. Ege Üniversitesi Sosyal Bilimler Enstitüsü, İzmir.

Yazıcılar, Ü. \& Bümen, N.T. (2019). Crossing over the brick wall: Adapting the curriculum as a way out. Issues in Educational Research, 29(2), 583-609. 


\section{APPENDiX 1: Interview Questions Form (Example)}

\section{Interview Questions}

1. As a teacher who works in a disadvantaged school, do you think that the national curriculum prepared by the MoNE can be implemented in its original form? Please explain. What are the difficulties you experienced in this process? What do you think are the causes of these difficulties?

2. What kinds of changes do you make in the curriculum for classroom use when you cannot implement it in its original form? What do you take into consideration when you plan your lessons?

3. Can you implement the content of instruction as recommended in the curriculum? What kinds of organizations/adaptations do you do about the content (facts, concepts, principles/generalizations in the topic). What do you take into consideration? Can you give examples?

4. How do you implement the methods and techniques recommended in the curriculum in the classroom environment? Can you give examples for these implementations? What kinds of adaptations do you do during adaptation? What do you take into consideration while doing adaptations?

5. Which instruction materials recommended in the curriculum do you find sufficient and effective? What kinds of adaptations do you do about the instruction materials? What do you take into consideration? Can you give examples?

6. How do you implement the assessment and evaluation activities and tools recommended by the curriculum in the classroom environment? What kinds of adaptations do you do about assessment and evaluation activities and tools? What do you take into consideration? Can you give examples?

7. How do you decide that you help students to acquire the attainments by demonstrating fidelity to curriculum? What are the criteria you use to decide whether the goals are realized or not?

8. What are the difficulties you face while implementing the curriculum? What do you think are the causes of these difficulties? Please explain.

9. How do you evaluate yourself in terms of curriculum adaptation? In what aspects do you think you are more competent? 